\title{
Taxonomy of the Early Middle Palaeolithic in Central Europe
}

\author{
Janusz K. Kozłowski
}

Abstract

Kivonat

\section{Keywords}

Kulcsszavak

Author - Szerző

Cite as • Hivatkozás

Article history •

Kézirat történet

Copyright • Jogok

(ㄷ)(1)\$
The objective of this paper is the analysis of cultural diversification in Central Europe, in the Penultimate Glaciation (MIS 8-6) on the basis of techno-morphological criteria. Using the taxonomic analysis of culture units in the Early Phase of the Middle Palaeolithic a hypothesis has been proposed that claims a complex, polycentric origin of some of the distinguished units that employed Levallois technology and bifacial tools such as Micoquian Keilmesser and leaf-points. The phylogenetic processes registered in the Early Phases of the Middle Palaeolithic determined the cultural diversity in the Late Phase of this time interval (from the Last Interglacial - MIS 5 - to the middle of the Interpleniglacial - MIS 3).

\begin{abstract}
A korai középső paleolitikum kulturális tagolódása Közép-Európában
A tanulmány célja, hogy technológiai-morfológiai szempontok alapján elemezzük a kulturális sokszínúség kialakulását Közép-Európában az utolsóelőtti eljegesedés (MIS 8-6) idején. A középső paleolitikum korai fázisában meglévő kulturális egységek taxonómiai vizsgálatára alapozva azt a hipotézist vetjük fel, mely szerint öszszetett, policentrikus eredettel rendelkeznek egyes, Levallois technológiát és bifaciális eszközöket - mint például Micoquien Keilmesser-eket és levélhegyeket - is használó iparok. A korai középső paleolitikum idején megfigyelt filogenetikai folyamatok meghatározták ezen időszak késői szakaszának kulturális sokszínűségét is, az utolsó Interglaciálistól (MIS 5) kezdve az Interpleniglaciális közepéig (MIS 3).
\end{abstract}

Middle Palaeolithic, Penultimate Glaciation, Mousterian, Micoquian, Levallois technology

középsố paleolitikum, utolsóelôtti eljegesedés, Moustérien, Micoquien, Levallois technológia

Janusz K. Kozłowski, Institute of Archaeology, Jagiellonian University, ul. Golębia 11, 31007 Kraków, Poland.

Kozłowski, J. K. (2016) Taxonomy of the Early Middle Palaeolithic in Central Europe (A korai középső paleolitikum kulturális tagolódása Közép-Európában). Litikum 4: 19-27. https://doi.org/10.23898/litikuma0016

Received | Érkezés: 2016. 04. 27. Accepted | Elfogadás: 2016. 12. 15. Published | Közzététel: 2017. 01. 29.

@ 2016 Kozłowski. Ez egy nyílt hozzáférésű publikáció, amit a Creative Commons 4.0 licensze véd. A termék szabadon használható, terjeszthető és sokszorosítható az eredeti szerző és forrás megjelölése mellett. | This is an open-access article distributed under the terms of the Creative Commons Attribution License, which permits unrestricted use, distribution, and reproduction in any medium, provided the original author and source are credited.

\section{Introduction}

This paper deals with the bases of taxonomy of the Early Middle Palaeolithic lithic industries, with particular emphasis on the origins of their diversification in the period of the Lower/Middle Palaeolithic transition. The base for taxonomic classification of Middle Palaeolithic assemblages are debitage technique: bifacial (Mode 2) and flake/blade (Mode 3) technologies. This distinction reflects norms of behaviours and cultural traditions handed on from generation to generation, that were, however, limited by the available raw materials. It should be emphasized that Mode 3 was not the effect of technological innovations but, rather, of the mastery and intensification of technical skills that determined Mode 2. It should be remembered that Mode 1 and Mode 2 cooccurred for a long time, especially in south-western Europe (Terradillos-Bernal, Díez-Fernández-Lomana 2012).Yet, these Modes cannot be assigned to a single anthropological group - i.e. either to Homo heidelbergensis or the Neanderthals - as both groups used the bifacial and blade/flake technologies.
Among bifacial technologies and tools produced by them we can distinguish:

a) Acheulian technology producing various types of symmetrical handaxes;

b) Micoquian technology aiming at the production of asymmetrical Keilmesser;

c) the technology of leaf-points production.

This division represents - to some extent - cultural traditions but the specific technologies are not a simple result of the évolution buisonnante of the Lower Palaeolithic Acheulian, but could have had polycentric origins in the effect of the interaction between Mode 2 and Mode 3.

This is the case of the relation between the Lower Palaeolithic Acheulian and Middle Palaeolithic units with bifacial technology (the Mousterian with Acheulian tradition and the Micoquian). While the Mousterian with Acheulian tradition is limited to western and southwestern Europe (Belgium, England, France, Spain), i.e. the territories of distribution of the Acheulian (Bordes 1950; White, Pettitt 1995), the range of the 


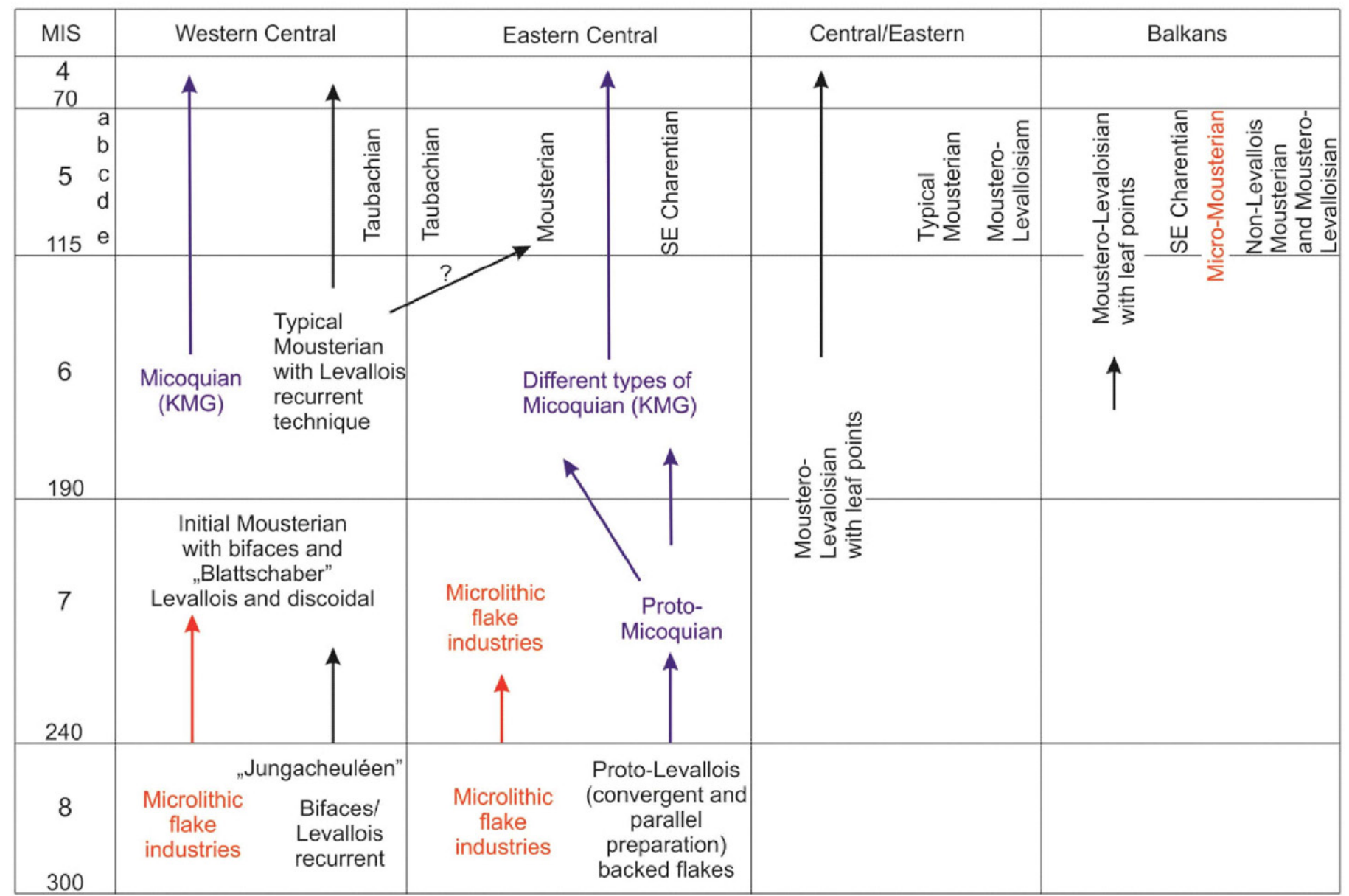

Figure 1. Chronological sequences and taxonomic differentiation in Central Europe between MIS 8 and MIS 5. // 1. ábra. Időrend és kulturális egységek Közép-Európában a MIS 8-MIS 5 időszakokban.

Micoquian or Micoquian-like industries, covering the territories of Germany, Poland, the Czech Republic, Slovakia, Hungary, Ukraine and the European part of Russia (Kozlowski 2006), extends markedly beyond the Movius-line (Movius 1948).

Moreover, the origins of the Micoquian cannot be restricted to the territories where the range of this unit and of the Acheulian overlap. The sequence in the eponymous site of La Micoque points to a late chronological position of the Micoquian level. At La Micoque the Micoquian occurs in level 6 dated to the early phase of the Last Glaciation (MIS 4). The underlying level 5 contained Acheulian handaxes, yet it is later than level 4 with the typical Mousterian. Thus, the Micoquian in south-western Europe is a much later phenomenon than in Central Europe where it appears already in isotope stage MIS 7 (Texier, Bertran 1993).

The relation between the Micoquian and the typical Mousterian has been claimed to be solely that of parallel cultural traditions. Attempts have been - just as in the case of the various facies of the Mousterian - to treat the two units as different stages of tool exploitation: unifacial tools representing a less advanced stage of tool use, and bifacial tools representing a more advanced stage of use and tool re-shaping (Soressi, Dibble 2003). On the basis of such a distinction J. Richter (2006) wants to interpret Mousterian sites as transient Summer occupations, and Micoquian sites as more stable Winter camps. Consequently, the morphological/typological diversity of forms within a specific technology would not, necessarily, represent a variety of final forms but, rather, reflect re-shaping in the effect of life-history of artefacts. However, this hypothesis seems unlikely as at other sites, except Sesselfelsgrotte (Richter 2006), no correlation exists between the Micoquian or the Mousterian and seasonality of camp occupation. It should be added that interference of the two units has also been registered.

Among unifacial technologies the basic difference is between flake technologies which do not determine blank forms and technologies that attempt to pre-determine the shape of the blank, namely

- various types of Levallois methods (unidirectional, centripetal recurrent, convergent, parallel) and

- volumetric blade debitage.

These two technologies belong to the set of norms of behaviours of specialized flint-knappers. At the same time, an important determinant of these norms was the availability and quality of raw materials.

The third level of taxonomic classification is blank re-shaping into different forms of retouched tools using various types of retouch. Among diagnostic tool groups belong sidescrapers, points, denticulated/notched tools, and Upper Palaeolithic type tools. At this level the interaction of a number 


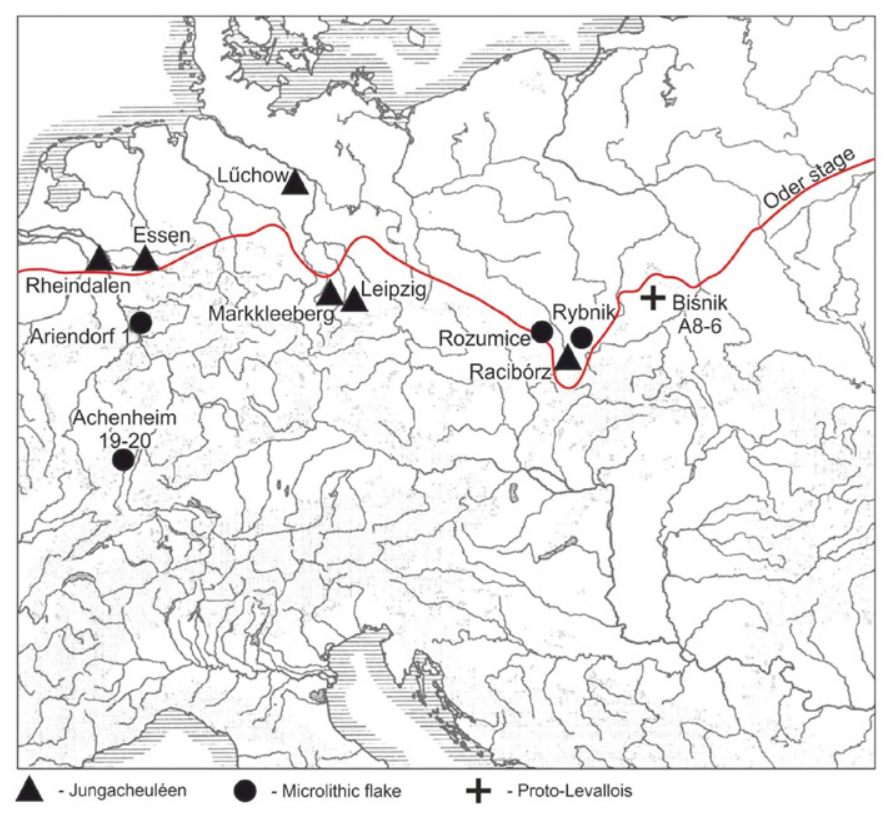

Figure 2. Map of Central Europe during MIS 8 (red line - Oder stage ice-sheet front). //

2. ábra. Közép-Európa a MIS 8 idején (vörös vonal - az Odera stadiálisban a jégtakaró kiterjedésének déli határa).
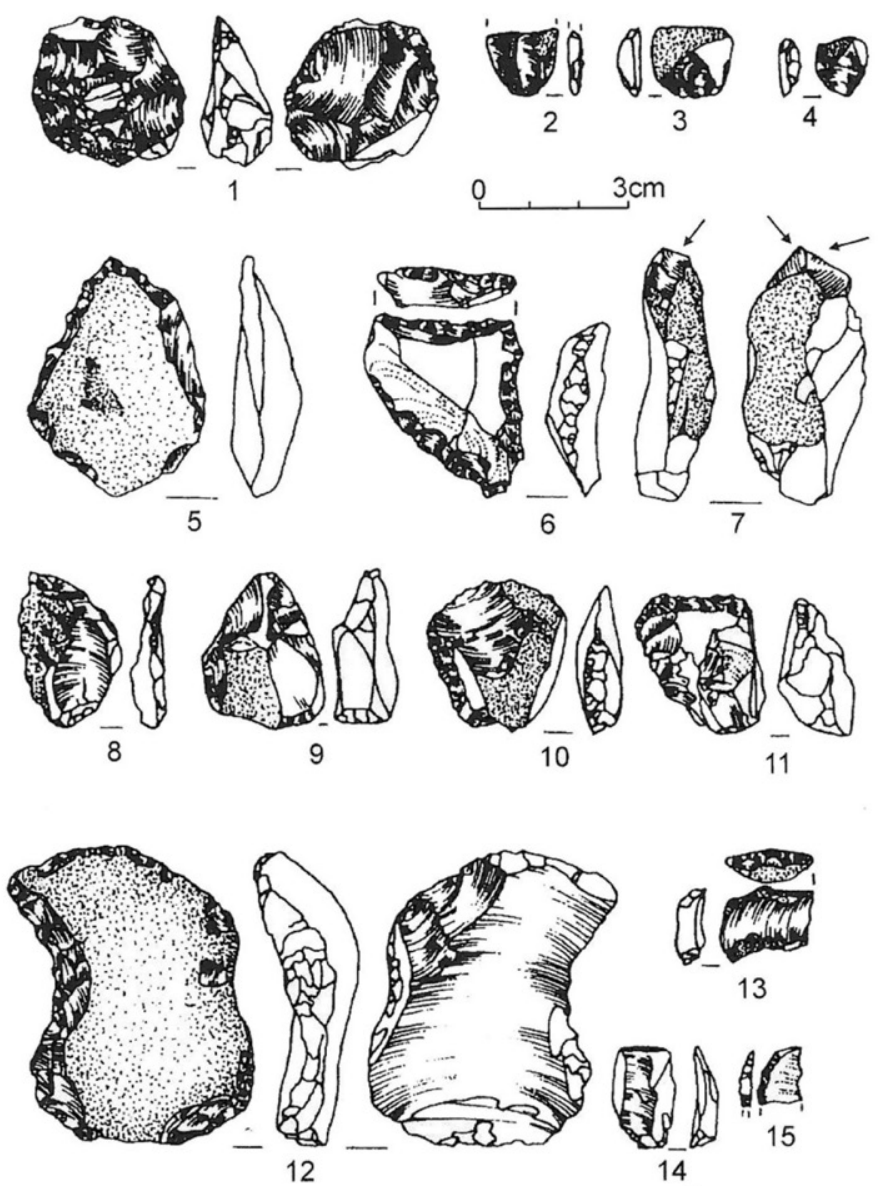

Figure 3. Rozumice 3 (Upper Silesia, Poland). Microlithic flake assemblage TL dated at 279 $\pm 17-253 \pm 17$ ka BP. //

3. ábra. Rozumice 3 (Felső-Szilézia, Lengyelország). Mikrolitikus szilánkegyüttes, TL kora 279 $\pm 17-253 \pm 17$ ka BP.

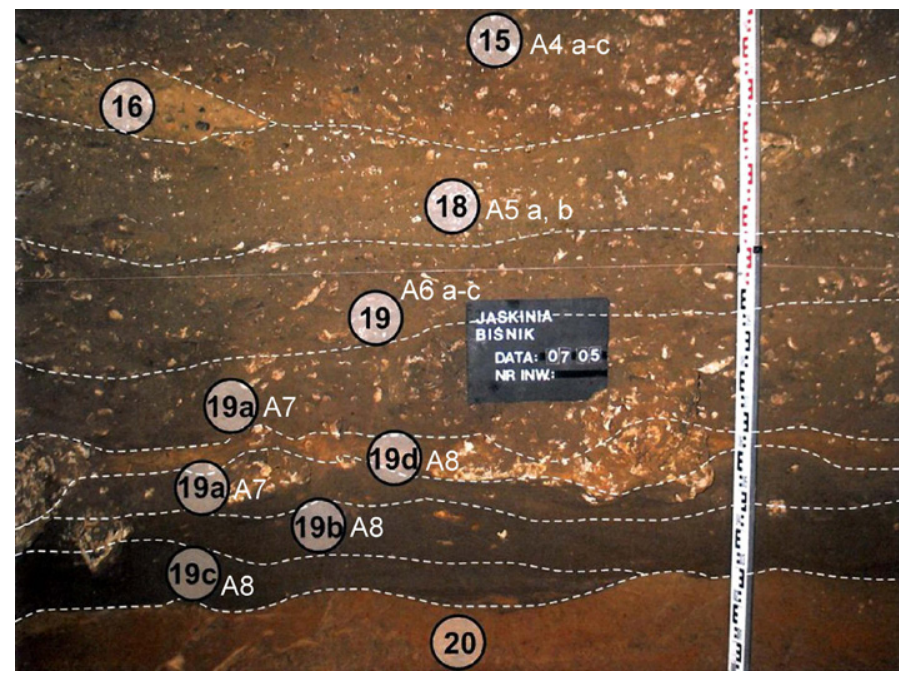

Figure 4. Biśnik Cave (Kraków-Częstochowa Jurassic Plateau, Poland). Profile of section S (layers 20-15, assemblages A8-A4a-c). (After Cyrek 2013) //

4. ábra. Biśnik-barlang (Kraków-Częstochowa-fennsík, Lengyelország). Az S metszetfal profilfotója (20-15. rétegek, A8-A4a-c kőegyüttesek). (Cyrek 2013 nyomán).

of factors is clearly noticeable: cultural tradition (which determines type of retouch and tool shapes, but also blank type), available raw materials, and tool maintenance registered as life history of an artefact.

An important stimulus of technological and morphological changes were climatic oscillations: from cool episodes partially related to the ice-sheet transgressions (MIS 8, 6, 4) to warmer interglacials or interstadials (MIS 7e, 7c, 7a, 5e, 5c, 5a). Adaptations to these conditions influenced the functional structure of lithic assemblages and the accessibility to raw materials.

\section{Taxonomic variability during MIS 8 (300-240 ka BP)}

In the period between MIS 8 and MIS 4 the Middle Palaeolithic taxonomic diversity reflects persistence of a variety of technological-morphological traditions, their modifications, and the emergence of new cultural entities (Bosinski 20002001; Kozłowski 2014) (Fig. 1).

The beginning of the Middle Palaeolithic is placed at MIS 8 stage when settlement expanded, for the first time, into the marginal zone of the Oder ice-sheet. In this period the following units are distinguished (Fig. 2):

a) The post-Acheulian represented by workshop sites in the Elbe and the Saale basin, with the largest site of Markleeberg. The most characteristic feature of this unit is the cooccurrence of two technologies: Mode 2 with bifacial tools and Mode 3 with a fairly well-developed Levallois technology. In its nature, the site of Markleeberg near Leipzig was a large workshop. The site has provided about 100,000 artefacts (Grahmann 1955; Baumann, Mania 1983).

b) The microlithic flake industries in the western part of Central Europe and in the Upper Oder basin (Ariendorf, Rozumice 3 - 279-253 ka BP). A distinctive feature of these 

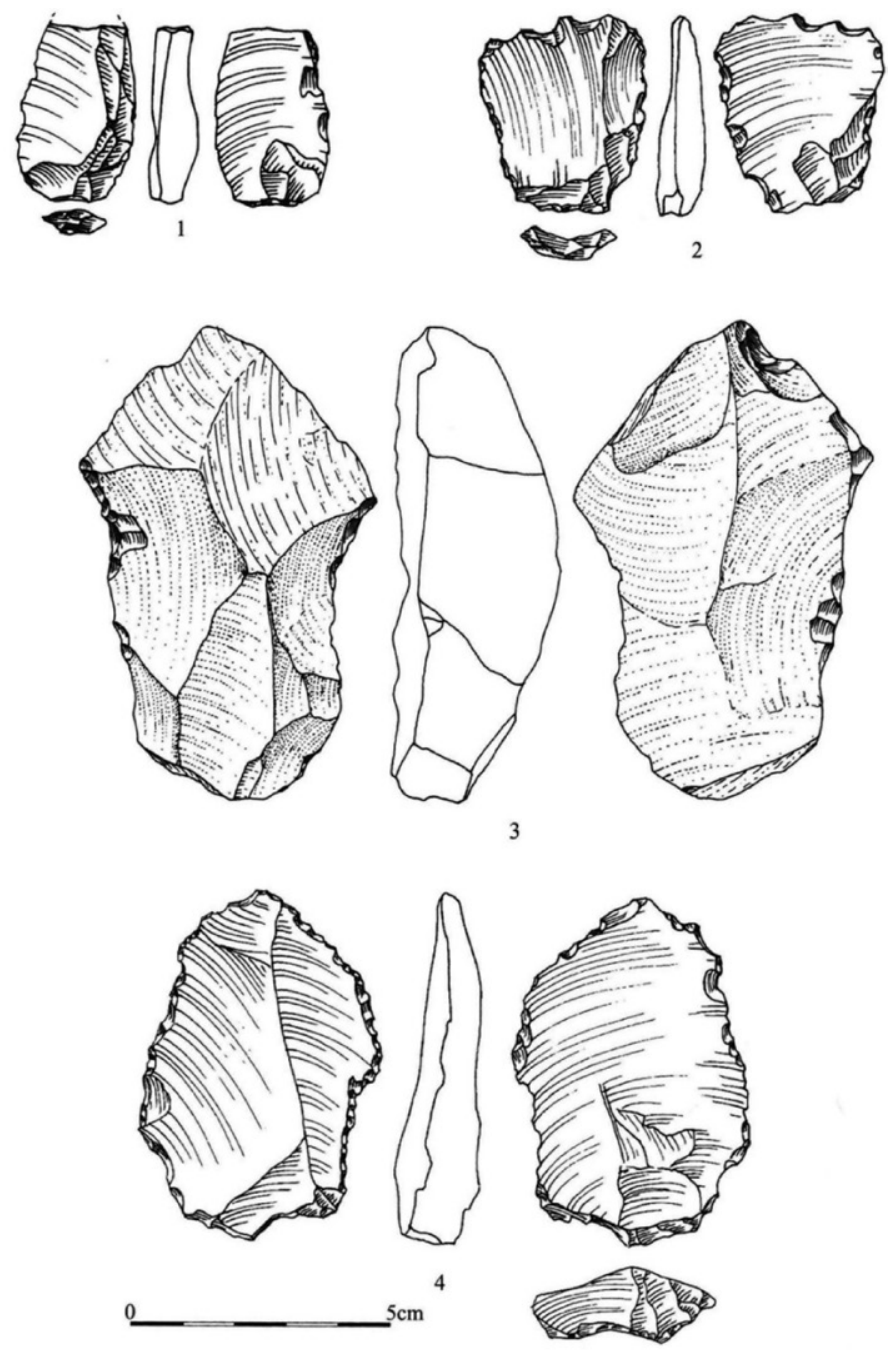

Figure 5. Biśnik Cave (Kraków-Częstochowa Jura, Poland). Assemblage A8 (layer 19b-d TL dated >279 ka BP). Protolevalloisian flakes. (After Cyrek 2013) //

5. ábra. Biśnik-barlang (Kraków-Częstochowa-fennsík, Lengyelország). A8 kőegyüttes (19b-d rétegek; TL kora >279 ka BP). Protolevalloisien szilánkok (Cyrek 2013 nyomán).

industries is microflake technology based on discoidal or irregular multiplatform cores. Flakes, frequently cortical, are retouched round the entire circumference, sometimes notched (Fig. 3). Sites with microlithic flake industries have provided not only hearths but also - at Rozumice 3 - a probable round dwelling structure built from erratic boulders (Foltyn et al. 2004).

c) The Protolevalloisian - the lowest part of the Biśnik Cave (layers 19b, c, d to 19; assemblages A8 to A6 - Cyrek 2002; 2013) TL dated at $>219 \mathrm{ka} \mathrm{BP}$ (Fig. 4). Prominent features are flakes with centripetal dorsal preparation, and prepared butts are characteristic. Flakes were retouched into lateral side-scrapers, or had lateral-transversal retouch, sometimes on the entire circumference (Fig. 5). Assemblage A6a contained tools with a blunted, weakly convex back (Cyrek 2013: Pl. VII). These tools - although with unilateral retouch - could be seen as prototypes of Micoquian knives (Fig. 6).
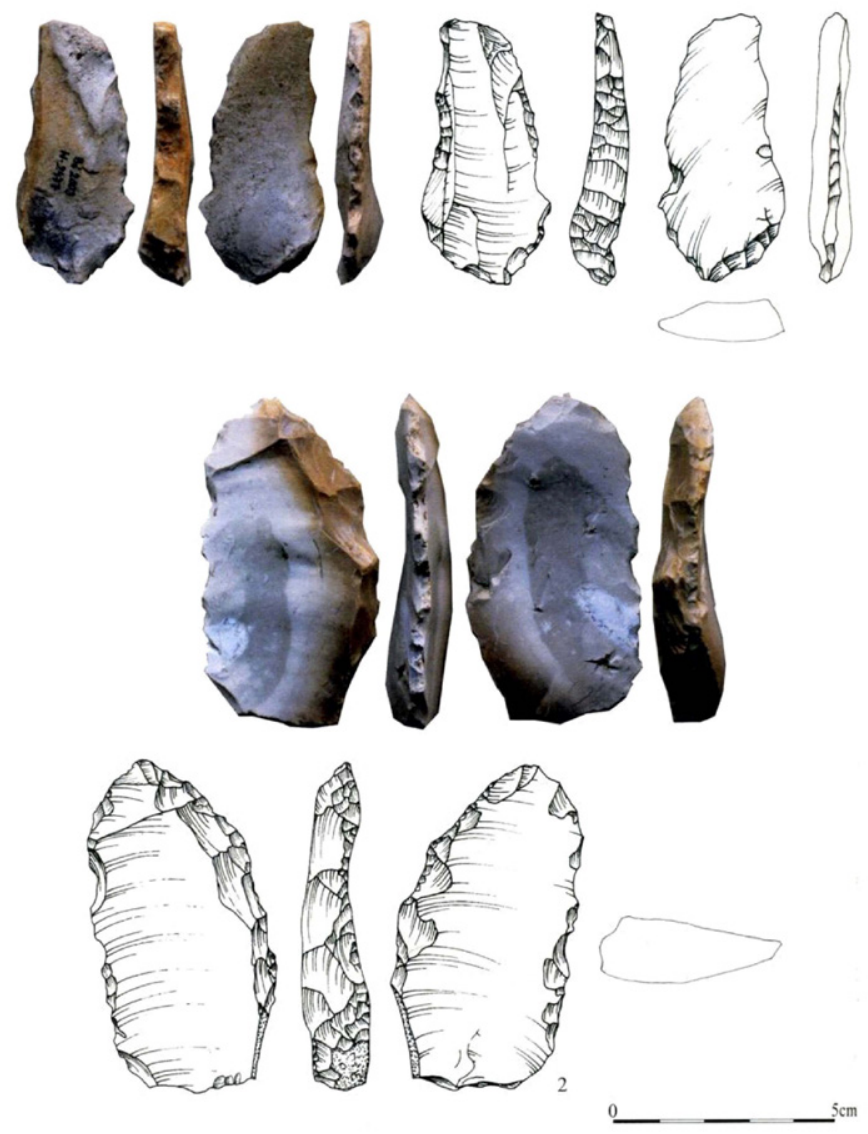

Figure 6. Biśnik Cave (Kraków-Częstochowa Jurassic Plateau, Poland). Assemblage A6a (layer 19 TL dated $279 \pm 97$ ka BP). Backed tools. (After Cyrek 2013) // 6. ábra. Biśnik-barlang (Kraków-Częstochowa-fennsík, Lengyelország). A6a kőegyüttes (19. réteg; TL kora >279 97 ka BP). Tompított hátú eszközök (Cyrek 2013 nyomán).

Thus Central Europe was dominated in isotope stages MIS 8-7 by the units that were rooted in the Lower Palaeolithic: in the western part of Central Europe in the Acheulian (Bosinski 1967), whereas in the northern part of Central Europe in the microlithic industries of Bilzingsleben-Vértesszőlős unit (Burdukiewicz, Ronen 2003; Burdukiewicz 2003). The initial stage of the Levallois technology known from the oldest assemblages in the Biśnik Cave seems to confirm the hypothesis forward in the literature (Gladilin, Sitlivy 1990; Kozlowski 2003; Wiśniewski 2014) that claims the origins of this technology in Central Europe independently of the western European Acheulian. One of the arguments in support is the very early appearance of Levallois technology at Korolevo in Transcarpathic Ukraine in the assemblage of layer VI (MIS 9) according to V. Stepanchuk (2006), although L. Kulakovska (2003) wants to see the first elements of its as late as layer V (MIS 7/MIS 6 boundary).

\section{Taxonomic variability during MIS 7 (240-190 ka BP)}

The period of MIS 7 between two transgressions of the Saalian Glaciation saw climatic amelioration. In Central Europe it was manifested by formation of travertine sediments in Thuringia and in Slovakia, by alluvial sedimentation (e.g. in 

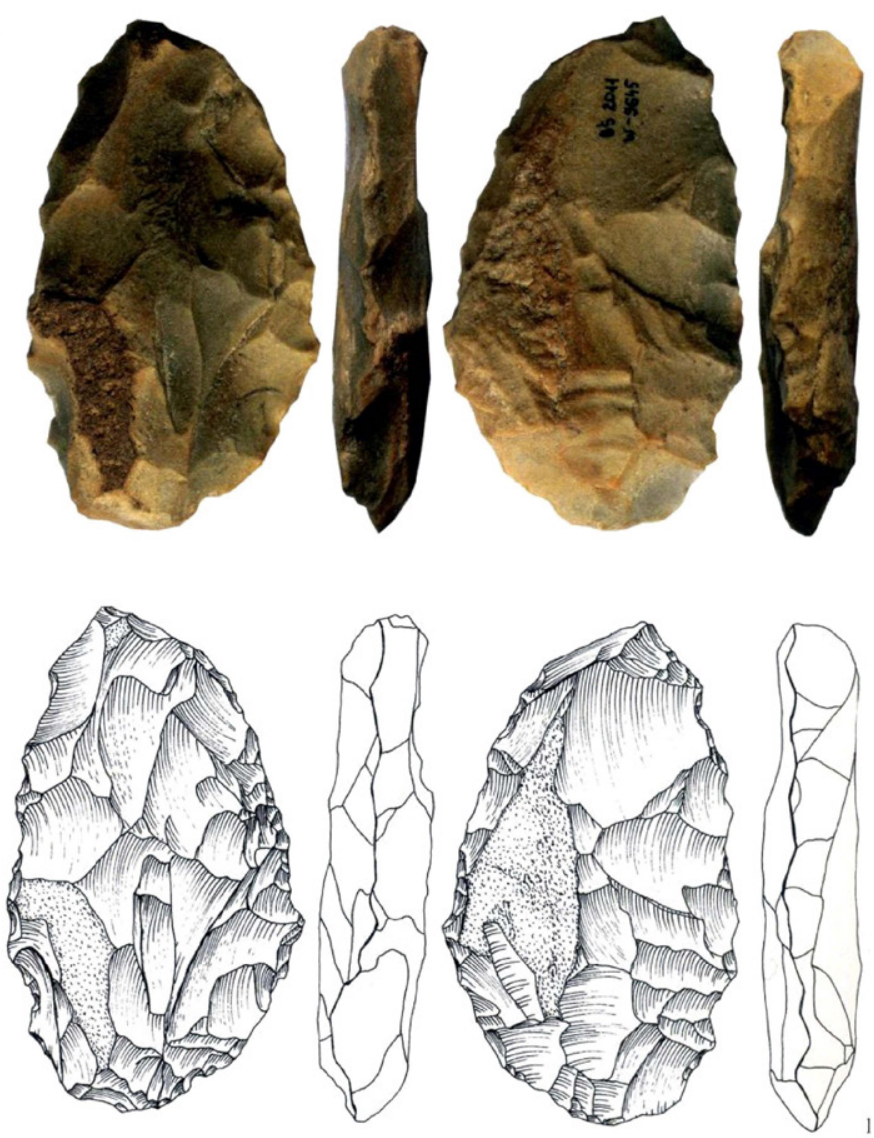

Figure 7. Biśnik Cave (Kraków-Częstochowa Jurassic Plateau, Poland). Assemblage A4a (layer 15, TL dated 195 $\pm 35 \mathrm{ka} \mathrm{BP}$ and U/Th dated $200 \pm 32$ ka BP). Proto-Micoquian bifacial Keilmesser. (After Cyrek 2013) // 7. ábra. Biśnik-barlang (Kraków-Częstochowa-fennsík, Lengyelország). A4a kőegyüttes (15. réteg; TL kora 195 \$35 ka BP, U/Th kora $200 \pm 32$ ka BP). Proto-Micoquien Keilmesser (Cyrek 2013 nyomán).

the Elbe basin ), by inter-loess soils (in the Carpathian Basin, in southern Poland and in Western Ukraine), also by lacustrine sediments (e.g. the Geisel valley in eastern Germany). Moreover, in cave sediments isotope stage MIS 7 can be marked by erosional processes with a major agency of water.

In the eastern part of Central Europe preserved sites from MIS 7 are more numerous. The following units have been distinguished:

a) The continuation of the post-Acheulian workshop type sites represented by the site of Hundisburg in eastern Germany where Levallois technology co-occurs with some few handaxes (Toepfer 1981).

b) The Proto-Micoquian (Keilmessergruppe, KMG) recognized in the sequence of the Biśnik Cave in layer 18 (assemblage A5a - TL dated on sediment and flints at $230 \mathrm{ka}$ BP), and layer 15 (assemblage A4a - U/Th dated at 200 $\pm 32 \mathrm{ka} \mathrm{BP}$ and TL dated on flints at 195 $\pm 35 \mathrm{ka} \mathrm{BP}$ ) (Cyrek 2013). While assemblage A5a (Fig. 7) is characterized by the presence of Levallois technology, with only one "Blattschaber" specimen (Cyrek 2013: Pl. XVI: 1) and one backed piece on a flake (Cyrek 2013: Pl. XV: 3), assemblage A4a provided a typical Micoquian bifacial Keilmesser (Cyrek 2013: Pl. XXV).
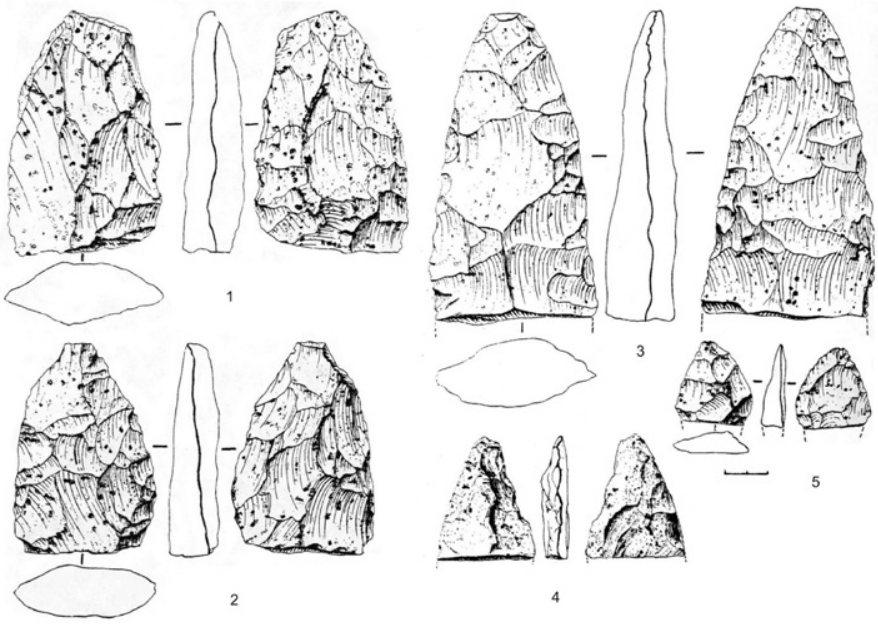

Figure 8. Korolevo II (Transcarpathian Ukraine). Leaf points: 1 - layer VI, 2-5 - layer Vb. (After Gladilin, Sitlivy 1990). // 8. ábra. Korolevo II (Kárpátalja, Ukrajna). Levélhegyek: 1 - VI réteg, 2-5 - Vb réteg (Gladilin, Sitlivy 1990 nyomán).

c) The Initial Mousterian with handaxes and Blattschaber, with Levallois and discoidal technology. This type of assemblages is known, mainly, from the western part of Central Europe. The most classical assemblages are embedded within travertines in Ehringsdorf near Weimar. The lower portion, U/Th dated at 245-190 ka BP, had formed in temperate, sub-continental conditions. Periodically, Mediterranean type of vegetation was also present. The Initial Mousterian shows a number of features in common with the typical Mousterian of the post-Eemian period: the prevalent discoidal technology, fairly thick blanks detached from discoidal cores. Blanks were steeply retouched into side-scrapers, points and limaces. Stepped retouch and even envahissante retouch were also used (Behm-Blanke 1960). The fauna associated with assemblages from these sites included Elephas antiquus, rhinoceros, horse, and beaver (Soergel 1922).

d) The microlithic flake industries continued to develop. Sites of this unit concentrate in the northern part of the Carpathian Basin, embedded, as a rule, in travertines. The most important site is Beharovce-Sobocisko that was initially attributed to MIS 5 (Bánesz 1961; Kaminská 2014), but - subsequently - the travertines at Beharovce provided an U/Th date of about 206 ka BP (Hausmann, Brunnacker 1988). The microflake industry, mainly on radiolarites, consists of denticulated-notched tools, retouched flakes and side-scrapers. The presence of microflake industries in the western part of Central Europe could, possibly, be claimed at the site of Neumark-Nord in the Geisel river valley, TL-dated at $204 \mathrm{ka}$ BP (Mania 2000). However, Neumark-Nord is a killing site where Rhinoceros kirchbergensis and Bos primigenius were hunted. The presence of Levallois technology makes the inventory from Neumark-Nord different from other microflake assemblages.

e) The Moustero-Levalloisian with leaf-points reached its easternmost range. This industry has been best recognized in Transcarpathian Ukraine. At Korolevo - the classical site of this unit - within the inter-loess soil (TL dated at 220 \pm 35 ka BP) layer 12 contained assemblages Vb and Va (Fig. 8) 


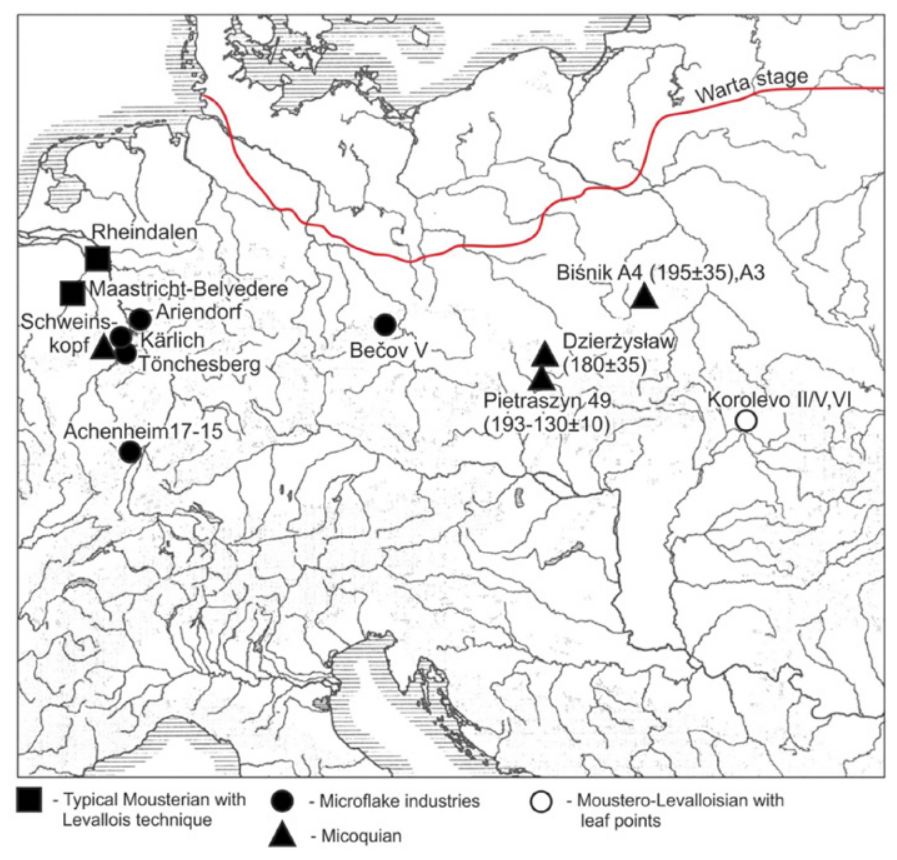

Figure 9. Map of Central Europe during MIS 6 (red line - Warta stage ice-sheet front). //

9. ábra. Közép-Európa a MIS 6 idején (vörös vonal - a Warta stadiálisban a jégtakaró kiterjedésének déli határa).

characterized by a well-developed Levallois technique in association with elongated leaf-points carefully shaped by bifacial retouch (Gladilin, Sitlivy 1990; Koulakovskaya 1995; 1999).

To sum up the cultural diversity in MIS 7: units from the initial phase of the Middle Palaeolithic (post-Acheulian workshop type sites and microlithic flake industries) are continued, simultaneously new units evolved such as the Micoquian (KMG), the Initial Mousterian of Ehrigsdorf type and the Moustero-Levalloisian with leaf-points. While the sequence in the Biśnik Cave indicates local origin of the Micoquian, the other three units do not have clear predecessors either in Central or in Eastern Europe.

\section{Taxonomic variability during MIS 6 (190-125 ka BP)}

In the period of the Warta stage ice-sheet transgression, despite the smaller range of the ice-sheet, settlement in Central Europe does not spread far to the north beyond the mountain ranges of the Beskids and the Sudetes (Fig. 9). Unlike in the Oder stage settlement does not extend close to the front of the ice-sheet. The most important taxonomic units, that existed in MIS 7 stage, such as the Micoquian, microflake industries and the Moustero-Levalloisian with leaf points still persist. Only in the western part of Central Europe a unit appears comparable to the typical Mousterian of the western European La Ferrassie type (Bosinski 2000-2001). no other new taxonomic units evolve in OIS 6.

Despite of continuity of earlier technological and morphological features in MIS 6 taxonomic units exhibit some differences in comparison with the units of MIS 7 stage viz. the distribution of cultural units and ways of exploitation of natural environments of cool loess steppe or even periglacial steppe. In MIS 6 stage the following units have been recognized:

a) The Micoquian (KMG), both with and without Levallois debitage. The facies without Levallois debitage is known from Pietraszyn in Upper Silesia TL dated at between $193 \pm 17$ and $130 \pm 10 \mathrm{ka} \mathrm{BP}$ (Fajer et al. 2001). It is characterized by the presence of asymmetrical bifacial Keilmesser and typical Micoquian handaxes (Fig. 10). A similar early date for the few bifacial tools was obtained from the site of Dzierżysław I (Upper Silesia): $180 \pm 35$ ka BP (Foltyn et al. 2000). The facies with Levallois debitage is represented by the assemblage from layer 14 (assemblage A3a) of the Biśnik Cave (Cyrek 2013). Distinctive features of this assemblage are fairly small assymetrical Keilmesser (Cyrek 2013: Pl. XLIV: 1, 2); unifacial backed forms (Cyrek 2013: Pl. XLIV: 3), similar to specimens in layer 19, continue to occur. In layer 14 (just as in layer 15) discoidal core technique and Levallois debitage co-occur with bifacial technique. Chronology of layer 14 is imprecise: for the lower boundary TL dates on flint gave 195-139 ka, but TL dates on sediment are younger (81 $\pm 17 \mathrm{ka}$ or even MIS 5/4).

b) Microflake industries occur in the territory of Germany (Achenheim layers 15-17 - Junkmanns 1991), and the Czech Republic (Bečov 5 - Fridrich 1982). The distinctive features of these industries are lateral side-scrapers and fine retouched flakes; sporadically small, bifacially retouched specimens also occur (Junkmanns 1991, Fig. 6:1).

c) Typical Mousterian with Levallois recurrent method is maintained in the western part of Central Europe, mainly in the upper level of the Older Loess, also in the volcanic sediments of the Rhein valley (Schweinskopf, Wannen). The sites of this facies were registered at Rheindalen-Ostecke B3 (Bosinski 2000-2001; Conard, Fischer 2000). The debitage technique and tool morphology resemble to the western European Mousterian of La Ferrassie type.

d) Levallois technology also persists east of the Carpathian mountain range, recorded in the sequence of Korolevo level II (Kulakovskaya 2009), and at other sites e.g. Velykyi Glybochok (Łanczont et al. 2014) or Buhliv V (Sytnyk 2000). Unfortunately, the correlation of absolute dates at these sites with the stratigraphy of loess levels and inter-loess soils is not always unequivocal. Nonetheless, the emergence of units with Levallois technology, also with leaf points, dates back in this part of Europe to stages MIS 8 (Protolevalloisian) and MIS 7 (Moustero-Levalloisian with leaf points). This chronology confirms the polycentric origins of Levallois technique proposed by A. Wiśniewski (2014). The polycentric model of the origins of Levallois technology associated with leaf-points is further confirmed by the presence of this association in the northern Balkans, most importantly in the sequence of the Kozarnika Cave (Bulgaria) where horizons 10c, 10b (Fig. 11) have been dated by palaeofauna to MIS 6 (200-130 ka) (Guadelli et al. 2005; Ferrier et al. 2009). Leaf-points, nearly oval in shape, occurred in the context of Levallois method with centripetal or bipolar preparation, with side-scarpers and denticulated tools (Sirakova 2009). 

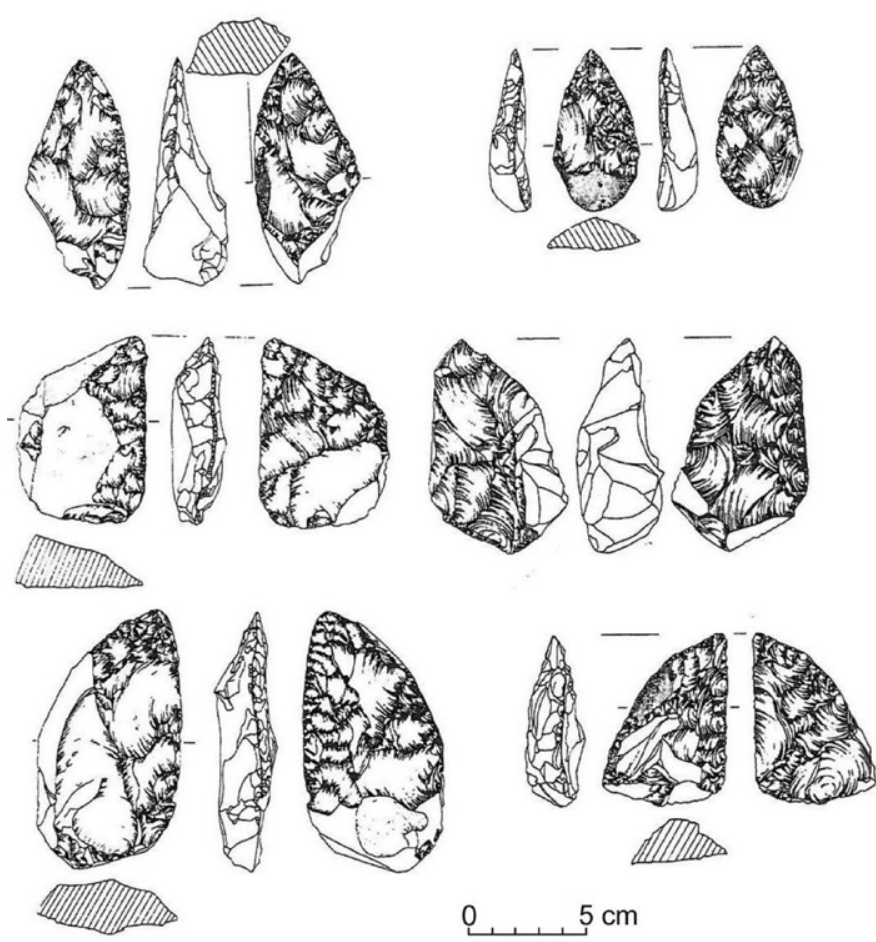

0

$5 \mathrm{~cm}$

Figure 10. Pietraszyn 49 (Upper Silesia, Poland). Micoquian implements TL dated at 193-130 ka BP. (After Fajer et al. 2001) // 10. ábra. Pietraszyn 49 (Felső-Szilézia, Lengyelország) Micoquien eszközök, TL koruk 193-130 ka BP. (Fajer et al. 2001 nyomán).

\section{Conclusions}

The evolution of the Early Phase of the Middle Palaeolithic, mainly in the Penultimate Glaciation, indicates polycentric origins of units whose typical attribute is the use of Levallois technology associated or not with bifacial tools, including the Central European Micoquian. These units developed independently of their Western European or South-Western European counterparts. Other units such as the microlithic flake industries evolved from local, Lower Palaeolithic techno-morphological traditions.

The phylogenetic processes described in this paper determined the cultural diversification during the Last Interglacial (MIS 5). In Central Europe emerged:

a) The Micoquian (KMG) as a continuation from MIS 7 and MIS 6. Micoquian facies, such as Könisgause A and Prondnician (Buhlen), evolved before MIS 4. Other facies (Bockstein, Klausennische) are first evident as late as MIS 4 and developed until the first half of MIS 3 (Bosinski 2000-2001; Kozlowski 2014).

b) The Taubachian (microlithic non-Levallois), continuing the microlithic flake tradition in MIS 5e (Taubach, Weimar, Kůlna layer 11-12 - Behm-Blanke 1960; Valoch 1988).

c) The Moustero-Levalloisian with leaf points (Ripiceni Izvor IV-V, Mamaia - Păunescu 1993; Temnata members 10-7 Sirakova 2009) and without leaf-points (Yezupil, Korolevo level II/III - Koulakovskaya 2009).

d) Typical Mousterian distributed across the whole Central Europe (e.g. Königsaue B - Mania, Toepfer 1973;
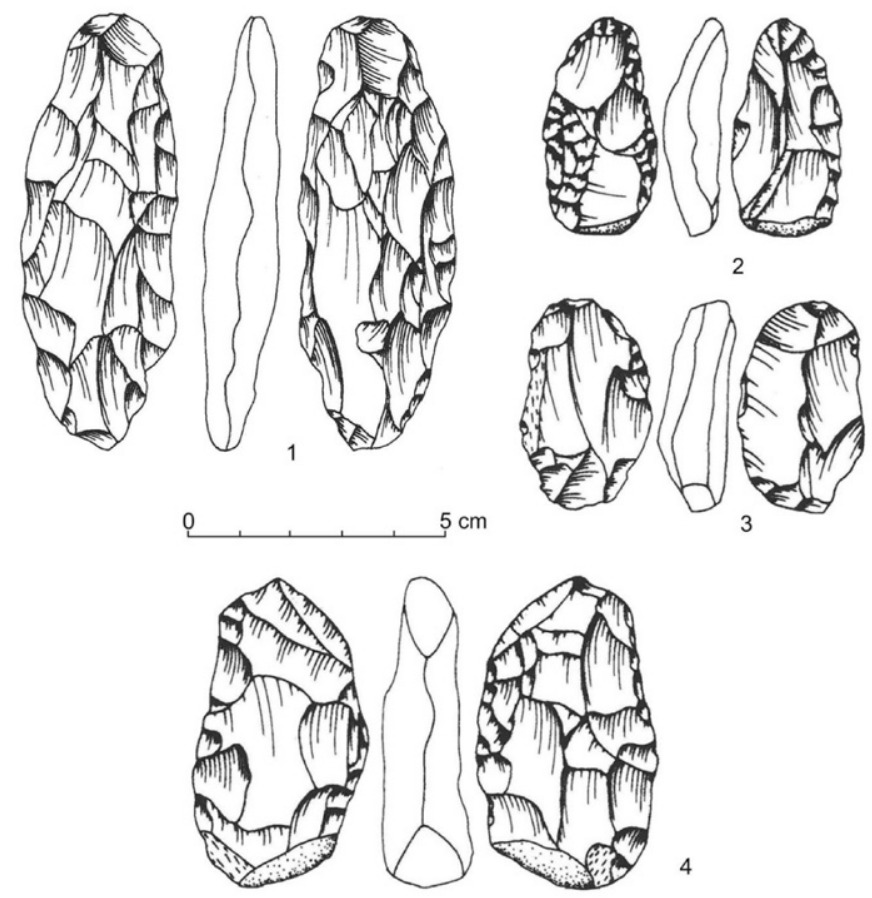

Figure 11. Kozarnika Cave (Bulgaria). Leaf points from layer 10a-10b (1-4), dated at 200-130 ka BP. (After Sirakova 2009) //

11. ábra. Kozarnika-barlang (Bulgária). Levélhegyek a 10a-10b (1-

4) rétegekből, koruk 200-130 ka BP (Sirakova 2009 nyomán).

Kraków-Zwierzyniec I 6, 7 - Kozłowski S. K. 2006; Bacho Kiro 14-12 - Kozłowski J. K. 1982).

e) SW Charentian (Krapina - Malez 1970), concentrated in the Western Balkans and the Middle Danube Basin.

The taxonomic units d) and e) are novel in the Last Interglacial in Central Europe. The processes of diversification of the Middle Palaeolithic units in Central Europe in the time interval from the Last Interglacial to the Early Phase of the Interpleniglacial have thus a complex polycentric nature (Kozłowski 2006). The beginnings of these processes reach back to the early phase of the Middle Palaeolithic when in the Penultimate Glaciation Central European Middle Palaeolithic units emerged independently of the Western and Eastern European, or even Mediterranean centres.

\section{References}

Bánesz, L. 1961. Prehl’ad paleolitu, východného Slovenska. Slovenská archeológia 9: 33-44.

Baumann, W., Mania, D. 1983. Die paläolithischen Neufunde von Markkleeberg bei Leipzig. Veröffentlichungen des Landesmuseums der Vorgeschichte Dresden 16, Berlin: Deutscher Verlag der Wissenschaften.

Behm-Blancke, G.1960.Altsteinzeitliche Rastplätzeim Travertingebiet von Taubach, Weimar, Ehringsdorf. Alt-Thüringen 4: 1-246.

Bosinski, G. 1967. Die mittelpaläolithischen Funde in westlichen Mitteleuropa. Fundamenta A4, Köln-Graz: Böhlau Verlag.

Bosinski, G. 2000-2001. El paleolítico medio en Europa Central. Zephyrus 53-54: 79-142.

Burdukiewicz, J. M. 2003. Technokompleks mikrolityczny w paleolicie dolnym środkowej Europy. Wrocław: Uniwersytet Wrocławski Instytut Archeologii. 
Burdukiewicz, J. M., Ronen, A. (eds) 2003. Lower Palaeolithic small tools in Europe and the Levant. BAR International Series 1115, Oxford: Archaeopress.

Conard, N., Fischer, B. 2000. Are there recognizable cultural entities in the German Middle Palaeolithic. In: Ronen, A., WeinsteinEvron, M. (eds), Toward modern humans: the Yabrudian and Micoquian 400-50 k-years ago. BAR International Series 850, Oxford: Archaeopress, 7-21.

Cyrek, K. (red.) 2002. Jaskinia Biśnik. Rekonstrukcja zasiedlenia jaskini na tle zmian środowiska przyrodniczego. Toruń: Wydawnictwo Naukowe Unywersytetu Mikołaja Kopernika.

Cyrek, K. 2013. Jaskinia Biśnik. Wczesny środkowy paleolit. Toruń: Wydawnictwo Naukowe Unywersytetu Mikołaja Kopernika.

Fajer, M., Foltyn, E. M., Foltyn, E., Kozłowski, J. K. 2001. Contribution à l'évolution du Micoquien en Europe centrale: nouvelles découvertes du Micoquien en Haute Silésie (Pologne). In: Cliquet D. (dir.), Les industries à outils bifaciaux du Paléolithique moyen d'Europe occidentale. E.R.A.U.L. 98, Liège: Université de Liège, 195-207.

Ferrier, C., Leblanc, J.-Cl., Berthet, A.-L., Delfour, G. 2009. La Grotte Kozarnika (Gara Oreshets, Bulgarie): données stratigraphiques, géologiques et sédimentologiques. In: Gatsov, I. (ed.), Saxa loquuntur. Sofia: Avalon, 13-27.

Foltyn, E. M., Foltyn, E., Kozłowski, J. K. 2000. Première evidence de l'âge pre-éémien des industries à pointes foliacées bifaciales asymétriques en Europe centrale. In: Ronen, A., Weinstein-Evron, M. (Eds), Toward modern humans: the Yabrudian and Micoquian 400-50 k-years ago. BAR International Series 850, Oxford: Archaeopress, 7-24.

Foltyn E., Foltyn, E. M., Kozłowski, J. K. 2004. Early Middle Paleolithic Habitation Structures from Rozumice Site C (Upper Silesia, Poland). In: Conard, N. J. (ed.): Settlement dynamics of the Middle Paleolithic and Middle Stone Age. Volume II. Tübingen: Kerns Verlag, 165-184.

Fridrich, J. 1982. Středopaleolitické osídlení Čech. Praha: Archeologický ústav ČSAV.

Gladilin, V. N., Sitlivy, V. I. 1990. Ашель Центральной Европы. Kiev: Nauk.

Grahmann, R. 1955. The Lower Palaeolithic site of Markkleeberg and Rother comparable localities near Leipzig. Transactions of the American Philosophical Society 45: 509-687. https://doi. org/10.2307/1005742

Guadelli, J.-L., Sirakov, N., Ivanova, St., Sirakova, Sv., Anastassova, E., Courtaud, P., Dimitrova, I., Djabarska, N., Fernandez, Ph., Ferrier, C., Fontugne, M., Gambier, D., Guadelli, A., Iordanova, D., Iordanova N., Kovatcheva, M., Krumov, I., Leblanc, J.-C., Mallye, B., Marinska, M., Miteva, V., Popov, V., Spassov, R., Taneva, St., Tisterat-Laborde, N., Tsanova, Ts. 2005. Une séquence du Paléolithique inférieur au Paléolithique récent dans les Balkans: la Grotte Kozarnika à Orechets (nord-ouest de la Bulgarie). In: Molines, N., Moncel, M.-H., Monnier, J.-L. (eds), Les premiers peuplements en Europe: - Colloque international: Données récentes sur les modalités de peuplement et sur le cadre chronostratigraphique, géologique et paléogéographique des industries du Paléolithique ancien et moyen en Europe (Rennes, 22-25 septembre 2003). BAR International Series 1364, Oxford: John and Erica Hedges Ltd,. 87-103.

Hausmann, R., Brunnacker, K. 1988. U-Series dating of the Middle European travertines. In: Schwarz, H. P. (coord.), L'Homme de Néandertal: Actes du colloque international de Liège (4-7 décembre 1986). Volume 1: La chronologie. E.R.A.U.L. 28, Liège: Université de Liège, 47-51.
Junkmanns, J. 1991. Die Steinartefakte aus Achenheim in der Sammlung Paul Wernert. Archäologisches Korrespondenzblatt 21/1: 1-16.

Kaminská, L. 2014. Staré Slovensko 2. Paleolit a mezolit. Nitra: Archeologický ústav SAV.

Kozłowski, J. K. 2003. From bifaces to leaf points. In: Soressi, M., Dibble H. L. (eds), Multiple Approaches to the Study of Bifacial Technologies. Philadelphia: University of Pennsylvania Museum of Archaeology and Anthropology, 149-164.

Kozłowski, J. K. 2006. Les Néandertaliens en Europe centrale. In: Demarsin, B., Otte, M. (dir.), Neanderthals in Europe. E.R.A.U.L. 117, ATVATVCA 2, Liège-Tongeren, 77-90.

Kozlowski, J. K. 2014. Middle Palaeolithic variability in Central Europe: Mousterian vs Micoquian. Quaternary International 326-327: 344-363. https://doi.org/10.1016/j.quaint.2013.08.020

Kozłowski, J. K. (ed.) 1982. Excavation in the Bacho Kiro Cave (Bulgaria): final report. Warszawa: Państwowe Wydawnictwo Naukowe.

Kozłowski, S. K. (ed.) 2006. Wylotne and Zwierzyniec. Paleolithic sites in Southern Poland. Kraków: The Polish Academy of Arts and Sciences-Warsaw University.

Koulakovskaya, L. 1995. Aspects typologiques des industries micoquiennes : le site de Korolevo en Ukraine. In: Les industries à pointes foliacées d'Europe centrale. Actes du Colloque de Miskolc, 10-15 septembre 1991. Paléo - Supplément $n^{\circ}$ 1, 207-211. https://doi. org/10.3406/pal.1995.1398

Kulakovskaya, L. V. 1999. Палеолитические местонахождения в районе Королево. Arkheologicheskiy Al'manakh Donietsk 8: 153-158.

Kulakovska, L. V. 2003. Середньопалеолітичні варіації на заході України. In: Варіабельність середнього палеоліту України. Куіv: Shliakh, 10-31.

Kulakovskaya, L. V. 2009. Королево: хронология раннего и среднего палеолита. In: Vasil'ev, S. A., Kulakovskaya, L. V. (red.), С. Н. Бибиков и первобытная археология. Sankt-Peterburg: Rossiyskaya Akademiya Nauk Institut Istorii Materialnoy Kultury-Natsionalnaya Akademiya Nauk Ukrainy Institut Arkheologii, 87-100.

Łanczont, M., Madeyska, T., Bogucki, A., Sytnyk, O., Kusiak, J., Frankowski, Z., Komar, M., Nawrocki, J., Zogała, B. 2014. Stratigraphic position and natural environment of the oldest Middle Palaeolithic in central Podolia, Ukraine: New data from the Velykyi Glybochok site. Quaternary International 326-327: 191212. https://doi.org/10.1016/j.quaint.2013.08.045

Malez, M. 1970. A new look at the stratigraphy of the Krapina prehistoric site. In: Malez, M. (red.), Krapina 1899-1969. Zagreb: Jugoslavenske akademije znanosti i umjetnosti, 40-44.

Mania, D. 2000. Stratigraphy and Palaeolithic of the Middle and Upper Pleistocene in the Saale-Elbe region. In: Ronen, A., Weinstein-Evron, M. (Eds), Toward modern humans: the Yabrudian and Micoquian 400-50 k-years ago. BAR International Series 850, Oxford: Archaeopress, 25-49.

Mania, D., Toepfer, V. 1973. Königsaue. Gliederung, Ökologie und mittelpaläolithische Funde der letzten Eiszeit. Berlin: Deutscher Verlag der Wissenschaften.

Păunescu, A. 1993. Ripiceni-Izvor paleolitic şi mezolithic. Biblioteca de arheologie 52, Bucureşti: Editura Academiei Române.

Richter, J. 2006. Neanderthals in their landscape. In: Demarsin, B., Otte, M. (dir.), Neanderthals in Europe. E.R.A.U.L. 117, ATVATVCA 2, Liège-Tongeren, 51-66.

Sirakova, S. 2009. Middle Palaeolithic leaf points from Bulgaria. In: Gatsov, I. (Ed.), Saxa loquuntur. Sofia: Avalon, 119-139. 
Soergel, W. 1922. Die Jagd der Vorzeit. Jena: Verlag von Gustav Fischer. Stepanchuk, V. N. 2006. Нижнй и средний палеолит украины. Chernovtsy: Zelena Bukovyna.

Sytnyk, O. 2000. Середній палеоліт Поділля. (Middle Palaeolithic of Podilia). Lviv: Natsionalna Akademiya Nauk Ukrainy.

Texier, J.-P., Bertran, P., 1993. Nouvelle interprétation paléoenvironnementale et chronostratigraphique du site paléolithique de la Micoque (Dordogne). Implications archéologiques. Comptes Rendus de l'Académie des Sciences de Paris 316(II): 1611-1617.

Terradillos-Bernal, M., Díez-Fernández-Lomana, J.-C., 2012. La transition entre les Modes 2 et 3 en Europe: le rapport sur les gisements du Plateau Nord (Péninsule Ibérique). L'Anthropologie 116(3): 348-363. https://doi.org/10.1016/j.anthro.2012.06.001

Toepfer, V., 1981. Das Acheuléen auf dem Boden der Deutschen Demokratischen Republik. Anthropologie (Brno) 19/1: 55-77.

Valoch K., 1988. Die Erforschung der Kůlna-Höhle 1961-1976. Brno: Moravské muzeum - Anthropos Institut.

Wiśniewski, A. 2014. The beginnings and diversity of Levallois methods in the early Middle Palaeolithic of Central Europe. Quaternary International 326-327: 364-380. https://doi. org/10.1016/j.quaint.2013.10.027 